\title{
FROM ASHUR TO NINEVEH: THE ASSYRIAN TOWN-PLANNING PROGRAMME
}

\author{
By MIRKO NOVÁK
}

\section{Introduction: Ashur and Nineveh}

During the last century of Assyria's existence the urban landscape was characterised by a bipolar structure. ${ }^{1}$ The old capital Ashur was still the religious, ceremonial and cultural centre, while Nineveh was the seat of royal power (Maul 1997). Both cities were not only the oldest urban entities of the Assyrian heartland, flourishing at least from the third or even fourth millennium $\mathrm{BC}$ onwards; they both also represented two different regions within Assyria with very specific geomorphologic environments and distinctive socio-ecological conditions. While the Ashur region is situated at the southernmost edge of the dry farming belt, the Nineveh area is one of the most fertile regions in northern Mesopotamia (Fig. 1).

The political fates of the two cities were unconnected for a long time. Ashur became an important trading centre and an independent kingdom at the beginning of the second millennium, whereas for a long time Nineveh stood in the shadow of more powerful neighbours. But in the seventh century it was Nineveh that became the capital of Assyria and the outstanding urban structure of the whole Near East. The refounding and enlargement of the city by Sennacherib was by far the most ambitious town-building programme ever realised in Assyria. Furthermore, it marked the end of a long process of moving the political centre of the country from the Ashur region northwards to the Nineveh region, which coincided with the rise of Assyria from a small kingdom to a world empire. During this development there were several (other) temporary capitals, all of them new foundations like Kār-Tukultī-Ninurta, Kalhu and Dūr-Šarrukēn.

The layouts of Ashur and Nineveh at that time differed so clearly, that no urbanistic connection is visible at first sight: on the one hand a relatively small town on top of a rock with all the important buildings crowded together near the periphery; on the other hand the spacious metropolis with its vast dwelling areas and huge palaces on top of high citadels. But did they really have nothing in common? Is there no urbanistic connection between both cities? To answer these questions it is necessary to look at the whole town-building programme through the centuries covering the Middle and Neo-Assyrian periods.

\section{Ashur}

The history of Ashur, the old capital that had given the country its name, dates back at least to the third millennium BC. ${ }^{2}$ It was situated on a triangular-shaped spur of the Mākhūl ranges, overlooking the narrow Tigris valley north of the confluence of the Tigris and lesser Zāb. This very specific geomorphological situation of the town is the reason for its atypical layout (Fig. 2). In contrast to the standard Babylonian town structure with the temple area in the city centre, all public buildings of Ashur were situated in a chain along the northern edge of the town, close to the steep slope of the rock.

The most prominent position at the peak of the spur was occupied by the temple and ziggurat of the main deity, the mountain god Ashur, who gave his name to "his" town (van Driel 1969; Maul 1997). Adjacent to these buildings was the old palace of the king, who was also the main priest of the god. The palace was adjacent to other important temples, for instance the temples of Anu and Adad, of Sin and Šamaš and of Ištar. The whole area of public buildings was bordered by quarters of private dwellings to the south. There was no fortification wall between the public and private areas.

Due to the geomorphological situation the whole town was built in the form of a triangle.

\footnotetext{
${ }^{1}$ The present paper is based on the thoughts and arguments developed in Novák 1999. I thank Cora Cieslak M.A. for improving the English manuscript.

${ }^{2}$ The history and archaeology of the city of Ashur are
}

presented in a number of publications of the excavators in the Wissenschaftliche Veröffentlichungen der Deutschen Orient-Gesellschaft. For a summary see Andrae 1977. On the recent excavations see Miglus 2000 and 2002. 


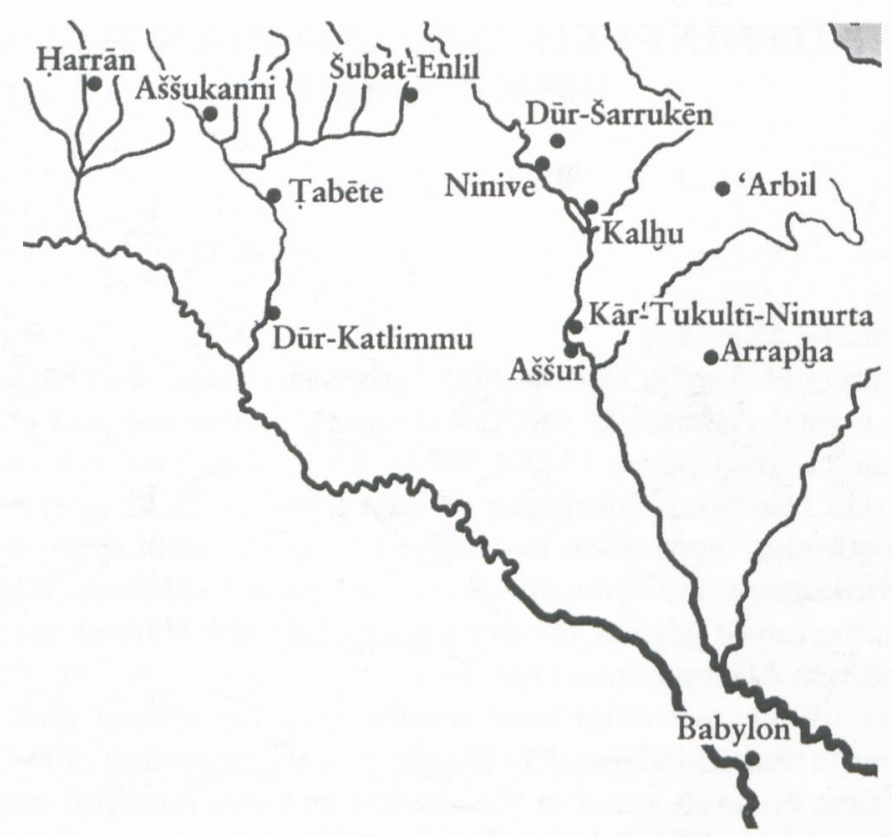

Fig. 1. Map of the heartland of Assyria.

When intramural space became scarce due to increased prosperity and power, the town was enlarged with the help of a new fortification wall, which enclosed a vast area to the south of the old town. The older part of the city became a kind of "inner town", known as libbi äli.

The layout of Ashur shows, first, that there was a concentration of public buildings at the northern periphery of the town and, second, that this area formed a landmark, visible from far away (Fig. 3). This characteristic structure is completely different from what is known from Babylonian sites at that period.

\section{The first foundations}

The rise of Ashur was, at the beginning, a result of its role as a trading centre, situated on one of the major routes connecting Babylonia with the north. However, the main disadvantage of the town was its small agricultural hinterland, which was centred in the Mākhmūr valley on the opposite bank of the river. From the very beginning, the Assyrian empire tried to expand to the north. In the time of Šamš̀-Addu I and again from the Middle Assyrian period onwards it incorporated the fertile region of the old urban centre of Nineveh. Therefore, the political centre of the state at that time was situated at its very southernmost periphery in a region of little agricultural potential.

This led to several attempts by Assyrian kings to shift the political and commercial centre away from Ashur which, as the seat of the national god, had to remain its spiritual, religious and ceremonial centre. The first attempt was made by Šamšì-Addu I who moved to Šehnā in the so-called "Hābūr triangle" and there established his new, short-lived capital Šubat-Enlil. ${ }^{3}$ The first serious building programme of an Assyrian residential city was the foundation of Kār-TukultiNinurta in the Mākhmūr valley, just a few kilometres north of Ashur (Fig. 4). ${ }^{4}$ The city was built on virgin ground, as stressed by King Tukulti-Ninurta I in his inscriptions (Weidner 1959: 28). Because it was erected in a flat area close to the riverbank, it could be constructed in a geometric layout. The whole city was enclosed by a rectangular fortification system. As at Ashur, the public buildings were concentrated in an area close to the riverbank and therefore were visible from outside the city, but unlike Ashur, this area was fortified and separated from the dwelling quarters.

\footnotetext{
${ }^{3}$ Located at modern Tell Leilān; on the excavations there see Weiss 1985 and 1991; Akkermans and Weiss 1988; Weiss et al. 1990.

${ }^{4}$ On the first excavations in Tukulti-Ninurta cf. Eickhoff
} 


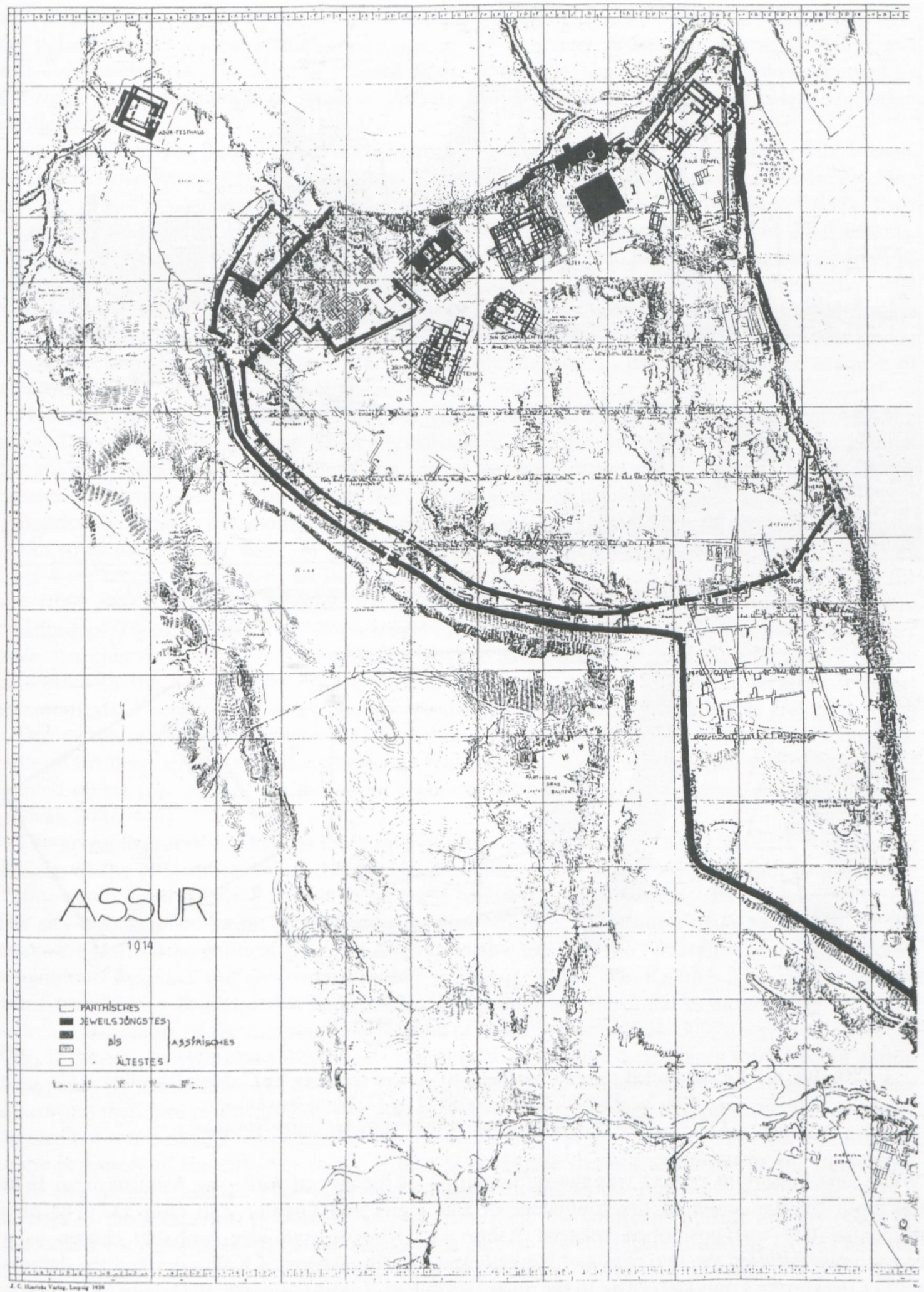

Fig. 2. Plan of Ashur (from Andrae 1977).

The reason for this may has been that a lot of deportees from occupied countries were settled within the city. These new inhabitants may have presented a certain danger, so that the royal elite felt forced to segregate themselves in a way previously unknown in Assyria. 


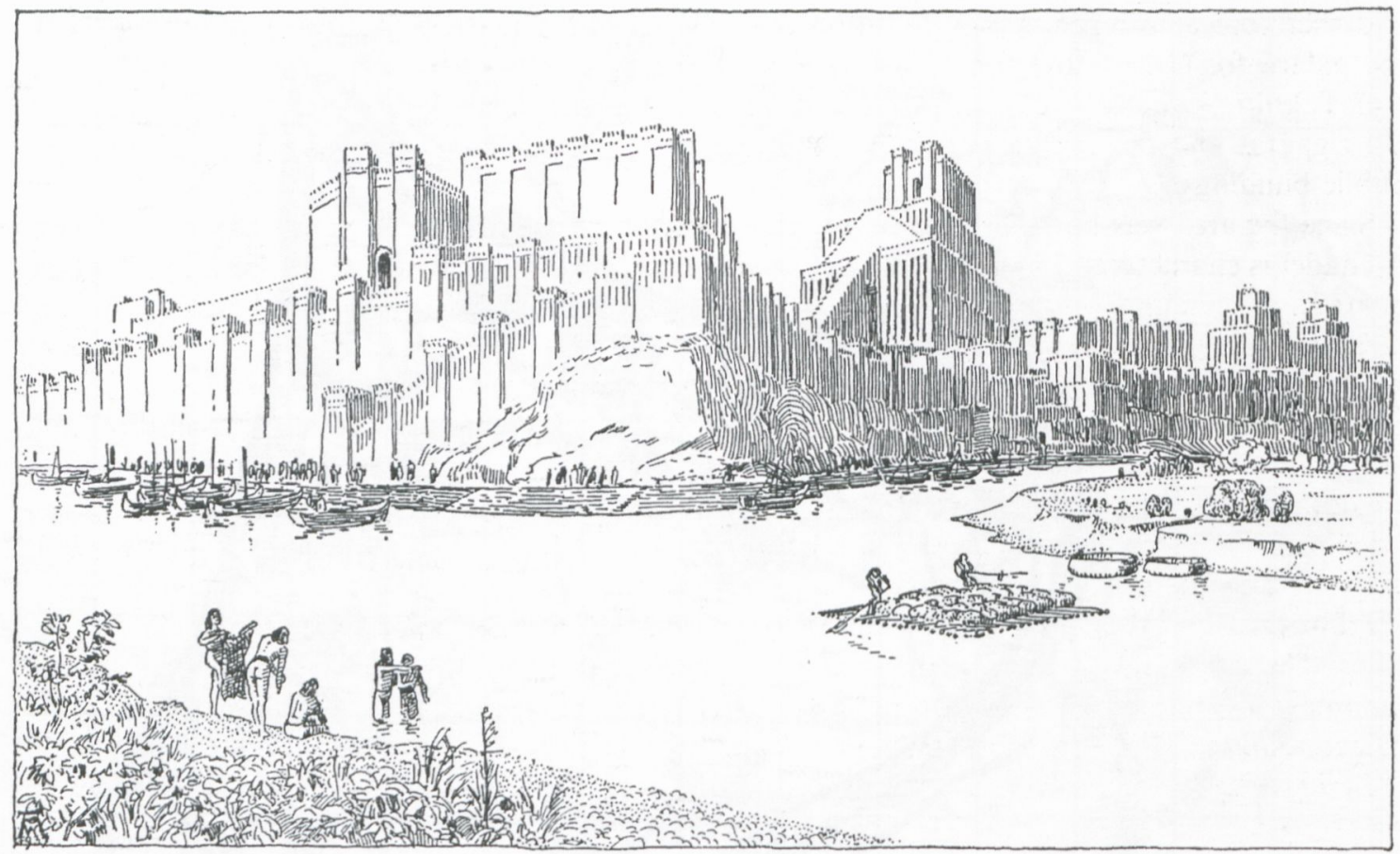

Fig. 3. Northern flank of Ashur seen from the Tigris valley (from Andrae 1977).
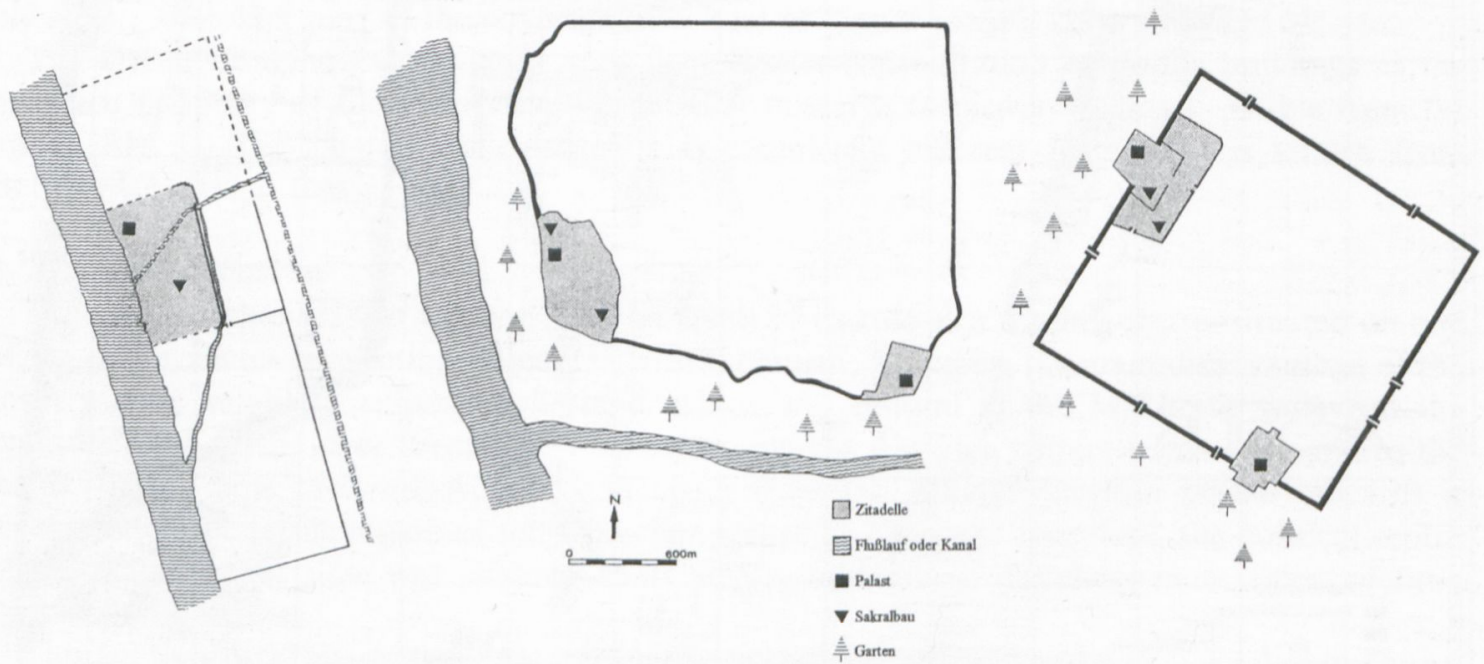

Fig. 4. Reconstructed plan of Kār-Tukultī-Ninurta (drawing by G. Elsen-Novák).

Fig. 5. Plan of Kalhu (drawing by G. Elsen-Novák).

Fig. 6. Plan of Dūr-Šarrukēn (drawing by G. Elsen-Novák).

The next important project was the refoundation of the city of Kalhu by Ashurnasirpal II in the ninth century, close to the confluence of the Tigris and Greater Zāb (Fig. 5). ${ }^{5}$ The new residential city was positioned between Ashur and Nineveh and was probably chosen as a compromise between the two regions. ${ }^{6}$ Nevertheless, the foundation of Kalhu marked the definite shift of the empire's political centre to the north. As in Kār-Tukultī-Ninurta, the layout is geometric with the exception of the southern edge. This edge followed the natural slope of the terrain towards the valley of the river. All the public buildings were situated on top of the artificial tell

\footnotetext{
${ }^{5}$ For an overview of the history and archaeology of the city, see Postgate and Reade 1976-80; on the inscriptions of Ashurnasirpal II see de Fillipi 1977.
}

${ }^{6}$ This theory is developed in Novák 1999: $131 \mathrm{ff}$. On the geographical context see Oates 1968: $58 \mathrm{ff}$. and Reade 1978. 
and therefore at a much higher elevation than the dwelling quarters. However, the temple and the palace formed a close spatial connection at the periphery of the city just as in Ashur and Kār-Tukulti-Ninurta. The most prominent place, at the very top of the citadel, was occupied by the ziggurat and the temple of Ninurta, the city god. It was close to the royal palace and other public buildings.

Since the area was both fortified and situated on a higher elevation, a real citadel was formed. A citadel is characterised by three features (Novák 1999: $302 \mathrm{ff}$.): it is separated from the dwelling quarters of the city by its own fortifications, it is situated on a higher elevation than the city itself and it is occupied only by public buildings and by the houses of the aristocracy and their servants. As far as we know, the first real citadels in this sense were created in Anatolia by the Hittites, as can be seen in Hattuša. It was a characteristic element of all the so-called "late Hittite" and Aramean towns like Sam'al, Karkamiš or Guzāna. We therefore have reason to believe that the creation of citadels may have been a result of western influence on Assyrian town planning principles (Bunnens 1996), but this is not necessarily the case, as can be seen by the example of a "proto-citadel" in Kār-Tukultī-Ninurta.

However, from the ninth century onwards, citadels became a characteristic feature of Assyrian cities. The citadel of Kalhu was physically connected with the city walls. Therefore, this created the image of public buildings "riding" on top of the fortification walls. A visitor could see the palaces and temples even from outside the city, situated high above the dwelling quarters.

Besides the citadel, some other innovations were introduced in Kalhu: the first was the extraurban royal garden and "zoo", in which were plants and animals from all conquered countries." They were meant to represent all the known parts of the world, just like the population of the city itself, which included deportees from all countries. The first known royal gardens were creations of Tiglath-pileser I in Nineveh and other sites, and they were now copied on a larger scale. Another new feature in Mesopotamia was the development of an open architecture for the palaces: with the help of "transparent" outer palace façades on top of the terraces, a visual communication between the landscape outside the city and the palace inside was created.

During the reign of Shalmaneser III, a third innovation was added to the layout of Kalhu. He built an artificial terrace near the southeastern corner of the city with another palace called ekal $m \bar{a} s ̌ a r t i$ on its top. Again, the palace architecture was characterised by open panorama rooms (Novák 2002: 446).

The urban layout of Kalhu was developed during a period of more than 150 years, its complete lifespan as the political centre of the empire. The pattern and all the elements that characterised Kalhu were copied by King Sargon II when he founded his new capital, Dür-Šarrukēn (Fig. 6). The city was built on virgin ground not far from Nineveh, its location marking the end of the successive shift of the political centre of Assyria northwards into the Nineveh region. The building programme included the environment of the city, as it had for Kalhu. ${ }^{8}$ The landscape was transformed into a fertile garden and park area, laid out "like the Amanus mountains" and filled with "all the plants of the mountainous regions of Hatti" (Fuchs 1994: 309; inscription in Room XIV, 11. 28-9). As orthostat reliefs show, pavilions with columned entrances were erected within these parks (Albenda 1986, Pls. 85-90). The general layout of Dūr-Šarrukēn was an almost perfect square and therefore much more regular and geometric than any other Assyrian city. The dominating element was a citadel which housed the public buildings (Fig. 7). As in Kalhu, it was situated at the periphery of the city, but unlike Kalhu, it broke the straight alignment of the outer limit of the city so that it extended partly beyond the basic square. In this outermost area of the citadel, the core of the palace was positioned, so that from there the landscape outside the city could be overlooked on three sides. Since the citadel was part of the fortification and its façade had the same decoration and structure as the city walls, the image of the terrace as "riding" on the walls was created. Seen from the outside, the palace was situated above the fortification walls and the gardens and thus visually prominent. But unlike Kalhu, the emphasis was now placed on the

\footnotetext{
${ }^{7}$ On royal gardens see Oppenheim 1965; Wiseman 1983 and 1984; Stronach 1990; Glassner 1991; Margueron 1992; Novák 2002.
}

\footnotetext{
${ }^{8}$ As described in the inscriptions of Sargon II; see Fuchs 1994.
} 


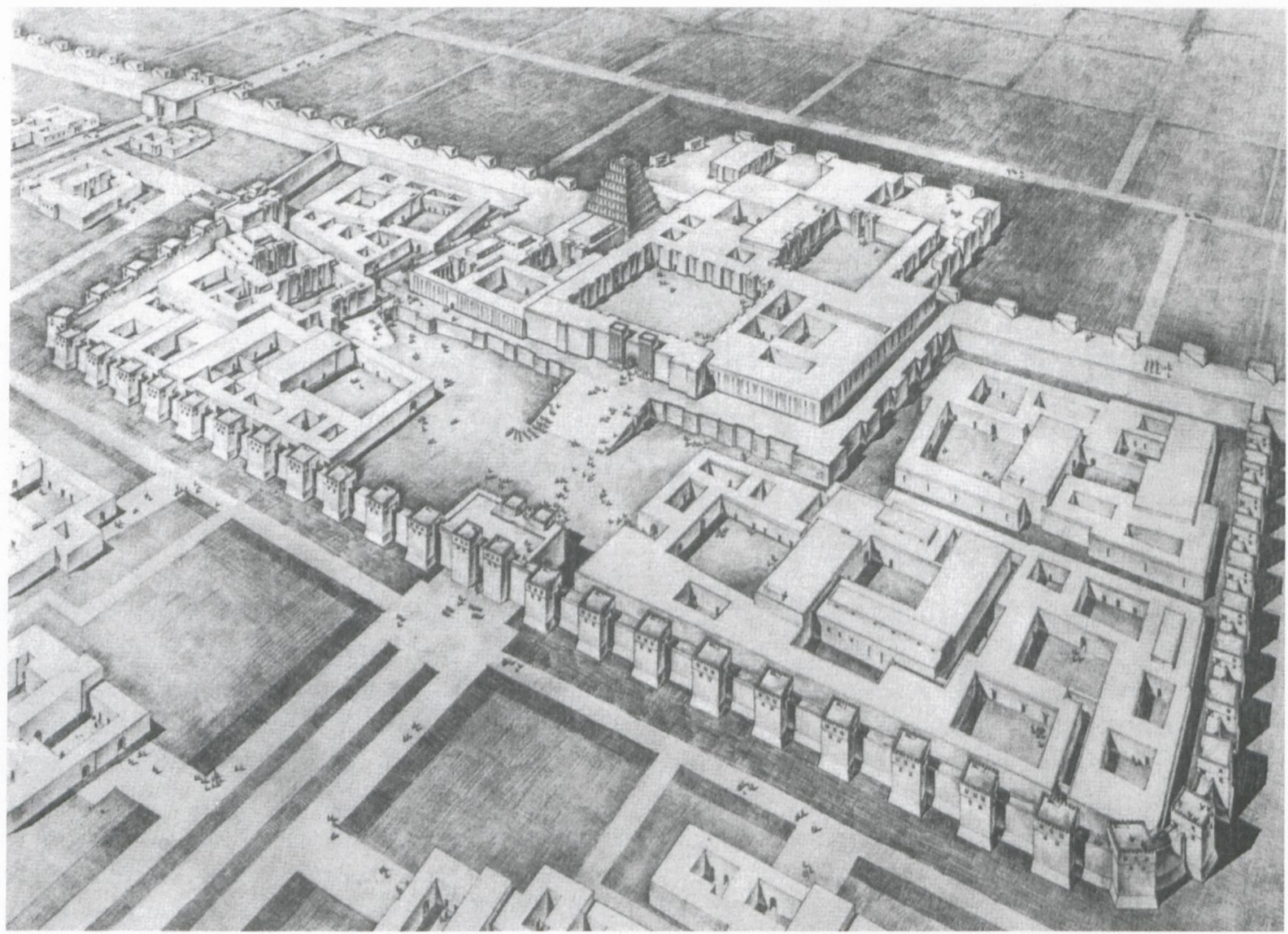

Fig. 7. Citadel of Dūr-Šarrukēn (from Loud and Altman 1938, frontispiece).

dominating palace instead of the temple. As at Kalhu, a secondary citadel with another palace was built on the southern flank of Dür-Šarrukēn and, like the main citadel, it broke the alignment of the city wall.

\section{Nineveh}

The last Assyrian capital was Nineveh, rebuilt by Sargon's son Sennacherib (Fig. 8). ${ }^{9}$ As before, the environment was transformed into artificial paradises and, once again, the landscape of the Amanus mountains was copied. Because descriptions and illustrations of the gardens exist, their position and design can be reconstructed. Again, pavilions with columned entrances were built within botanical gardens that were irrigated with the help of aqueducts. Wild animals were kept inside, and killed in ceremonial hunts. Two artificial mounds close to the river bear witness to the long history of Nineveh. Both were transformed into citadels: the larger one (Kuyunjik) into the main citadel and the smaller one (Nebi Yunus) into the secondary citadel. The general structure was therefore the equivalent of the ones of Kalhu and Dūr-Šarrukēn. On top of the main citadel and close to its edges, the palaces of Sennacherib and Ashurbanipal were erected, while temples occupied the centre. Since the palace of Sennacherib lay close to the western slope of the citadel, it overlooked the riverside and the gardens. Hence, the façade of the palace was visible from outside the city. This situation can be seen on a bas-relief (Fig. 9) that depicts Nineveh (Reade 1998: 86 f.): above three rings of fortifications, a double hilāni façade, each with two columns, can be seen. The lower two walls with a city gate (Gate 13, the so-called "mušlălu of the palace") can be identified as the two city walls attested by excavations. The third wall may have been the glacis of the citadel. The hiläni façade was the part of Sennacherib's palace that was visible from outside the city. It gave the impression of "transparent" architecture "riding" on top of a strong fortification system. To summarise, it is evident that the layout and structure of Nineveh followed

\footnotetext{
${ }^{9}$ On the inscriptions of Sennacherib see Luckenbill 1924 and Frahm 1997; on the layout of the city see Reade 1998-2001.
} 


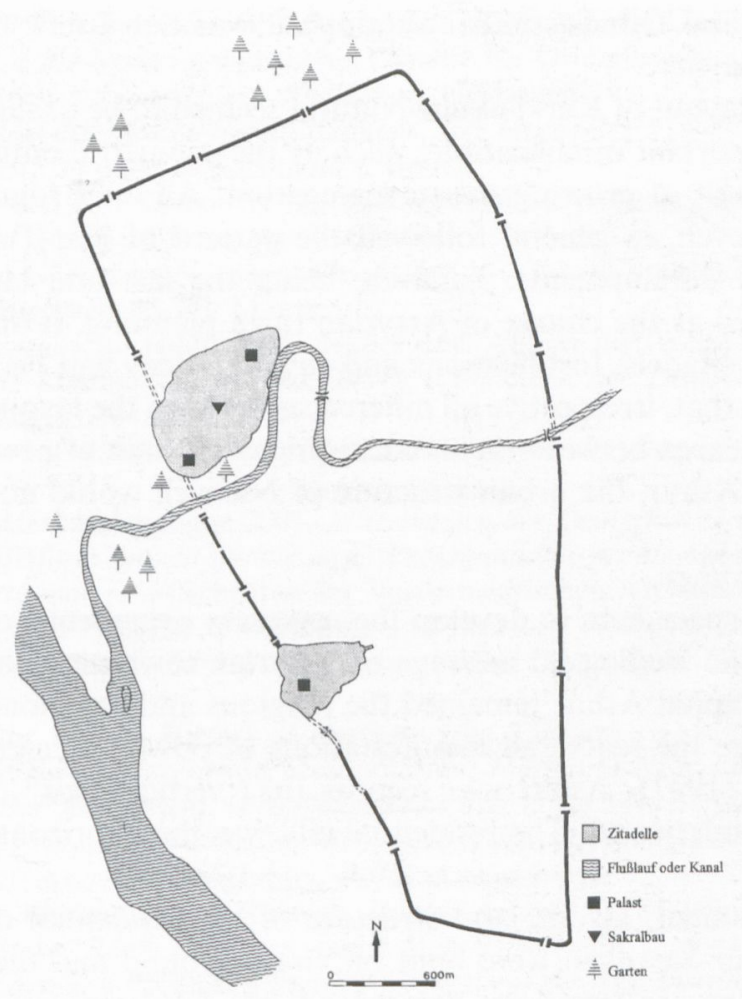

Fig. 8. Plan of Nineveh (drawing by G. Elsen-Novák).

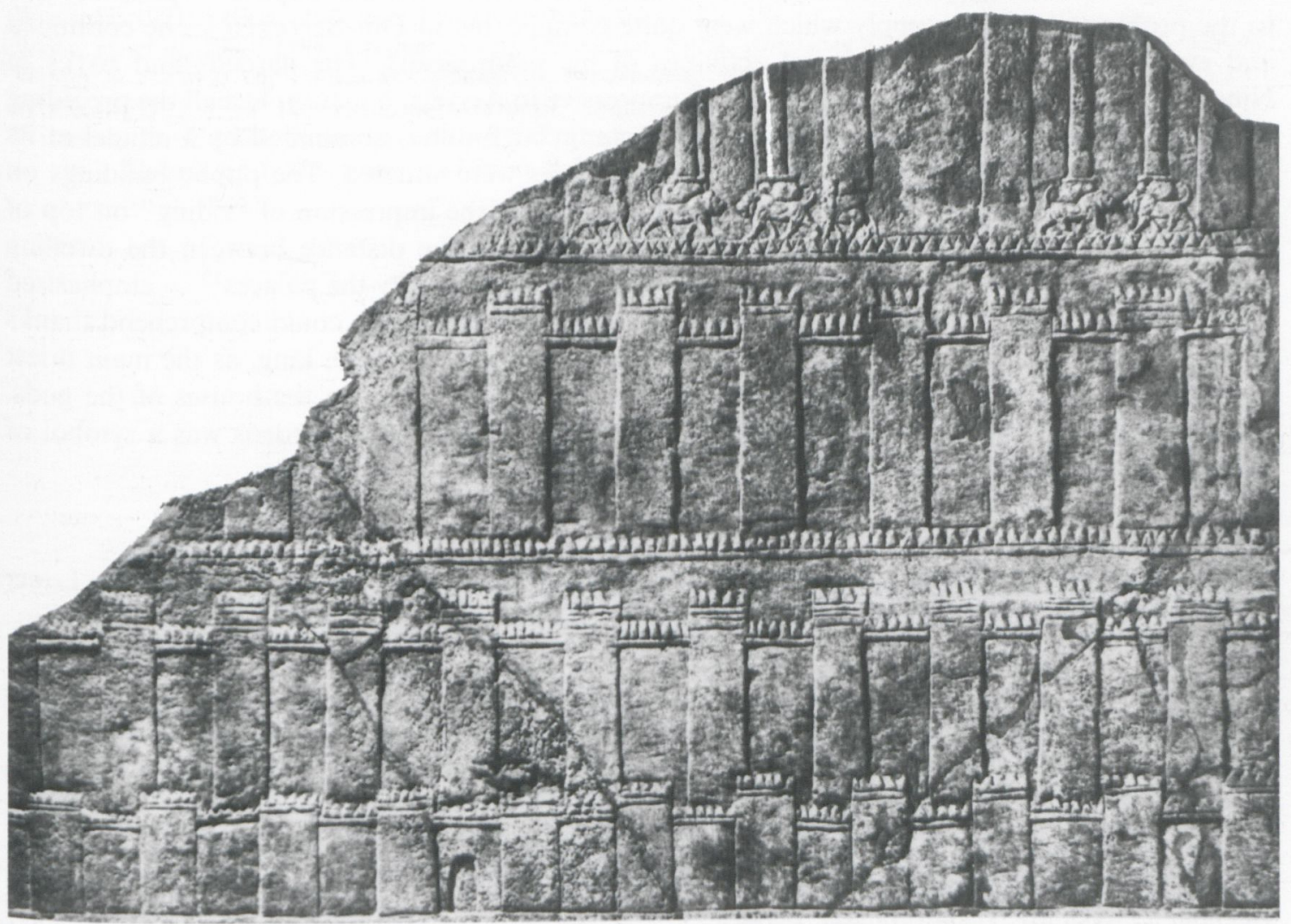

Fig. 9. Neo-Assyrian relief from Nineveh showing the exterior of Nineveh with the city walls and palace façade (from Orthmann 1975, Fig. 241). 
the tradition of Kalhu and Dūr-Šarrukēn, although it was not a new foundation, but simply a re-creation of an age-old city.

As we have seen, the layout of Kār-Tukulti-Ninurta seemed to be a (slight) copy of the structure of Ashur with some important modifications, such as the geometric outline and the creation of a "proto-citadel" as a result of growing urban segregation. All later foundations, such as Kalhu, Dūr-Šarrukēn and Nineveh, in general followed the pattern of Kār-Tukultī-Ninurta with some significant changes and developments. Nineveh, being the last and largest political capital of Assyria, can be described as the climax of Assyrian town planning. It also shows how important urban elements such as citadels, fortifications and royal gardens had become.

We can now conclude that, irrespective all differences between the layouts of Ashur and Nineveh, a structural connection exists between them, consisting of a chain of newly-built residential cities. Without the pattern of Ashur, the urban structure of Nineveh would not have been the same.

\section{Town planning and ideology}

Although there is no space here to develop the necessary arguments, one further aspect should be mentioned, namely the ideological message of Assyrian town-planning projects (Novák 1999: $385 \mathrm{ff}$.). While the old capital Ashur remained the religious and ceremonial centre of the country, the residential cities were the seats and manifestations of power, created artificially by the king. To quote Stefan Maul (1997), Ashur was seen as the "vertical axis" of the world, connecting heaven, earth and the underworld. The residential city was the "horizontal axis", the centre of all the power in the world.

The position, environment, layout, and structure of the residential cities illustrate this: KārTukultī-Ninurta and Dūr-Šarrukēn were built on virgin ground and therefore demonstrated the ability of the Assyrian king to transform desert land into fertile country. This was accomplished by horticulture, creating landscaped parks, botanical gardens and "zoos" with plants and animals from all the conquered countries now subordinate to the Assyrian king.

Although Sennacherib chose the ancient town of Nineveh for his new capital — probably due to the problems of water supply which were quite complicated in Dūr-Šarrukēn - he continued and even surpassed the horticultural activities of his predecessors. The gardens and parks of Nineveh were the greatest and surely the most impressive in Assyria. Nineveh, like all the preceding Assyrian residential cities, had a more or less rectangular outline, dominated by a citadel at its periphery where the royal palaces and the main temples were situated. The public buildings on top of the citadel were partly visible from outside and gave the impression of "riding" on top of the fortification walls high above the elevation of the city. The distance between the dwelling quarters of the common people and the public buildings - primarily the palaces ${ }^{10}$ — emphasised the almost supernatural position of the king, a message that everybody could comprehend thanks to visual communication between the inside and outside of the city. The king, as the main priest and representative of the god Ashur, lived high above the city, close to the houses of the gods. The city with its "international" inhabitants and the artificial paradise gardens was a symbol of the whole empire, and hence of royal power.

\section{Bibliography}

Akkermanns, P. and Weiss, H. 1988: Tell Leilan 1987 Operation 3: A Preliminary Report on the Lower Town Palace. Les annales archéologiques arabes syriennes 37/38, 91-109.

Albenda, P. 1986: The Palace of Sargon, King of Assyria. Paris.

Andrae, W. 1977: Das wiedererstehende Assur (2nd edition, edited by B. Hrouda). Munich.

Bunnens, G. 1996: Syro-Anatolian Influence on Neo-Assyrian Town Planning, in: G. Bunnens (ed.), Cultural Interaction in the Ancient Near East (Abr-Nahrain Supplement Series 5), 113-28. Leuven.

Dittmann, R. 1990: Ausgrabungen der Freien Universität Berlin in Assur und Kār-Tukultī-Ninurta in den Jahren 1986-89, Mitteilungen der Deutschen Orient-Gesellschaft 122.

Dittmann, R. et al. 1988: Untersuchungen in Kār-Tukultī-Ninurta, Mitteilungen der Deutschen OrientGesellschaft 120.

van Driel, G. 1969: The Cult of Aššrur. Assen.

Eickhoff, T. 1985: Kār-Tukulț-Ninurta. Berlin.

\footnotetext{
${ }^{10}$ On the architecture of the palaces cf. Heinrich 1984; on their ideological message cf. Winter 1993.
} 
de Filippi, W. 1977: The Royal Inscriptions of Aššur-nāsir-apli II, Assur 1/7, $123-69$.

Frahm, E. 1997: Einleitung in die Sanherib-Inschriften (Archiv für Orientforschung Beiheft 26). Vienna.

Fuchs, A. 1994: Die Inschriften Sargons II. aus Khorsabad. Göttingen.

Glassner, J. J. 1991: À propos des jardins mésopotamiens, Res Orientales 3, 9-17.

Heinrich, E. 1984: Die Paläste im alten Mesopotamien. Berlin.

Loud, G. and Altman, Ch. B. 1938: Khorsabad II (Oriental Institute Publications 40). Chicago.

Luckenbill, D. D. 1924: The Annals of Sennacherib. Chicago.

Margueron, J. C. 1992: Die Gärten im Vorderen Orient, in: M. Carroll-Spillecke (ed.), Der Garten von der Antike bis zum Mittelalter, 45-80. Mainz.

Maul, S. 1997: Die altorientalische Hauptstadt: Nabel und Abbild der Welt, in: G. Wilhelm (ed.), Die orientalische Stadt: Kontinuität, Wandel, Bruch (Colloquien der Deutschen Orient-Gesellschaft 1), 109-24. Saarbrücken.

Miglus, P. A. 2000: Assur. Frühjahrskampagne 2000, Mitteilungen der Deutschen Orient-Gesellschaft 132, $13-54$.

Miglus, P. A. 2002: Assur. Herbstkampagne 2001, Mitteilungen der Deutschen Orient-Gesellschaft 134, 7-39.

Novák, M. 1999: Herrschaftsform und Stadtbaukunst. Programmatik im mesopotamischen Residenzstadtbau von Agade bis Surra man ra'ā (Schriften zur Vorderasiatischen Archäologie 7). Saarbrücken.

Novák, M. 2002: The Artificial Paradise. Programme and Ideology of Royal Gardens, in: S. Parpola and R. M. Whiting (eds.), Sex and Gender in the Ancient Near East, Proceedings of the $47^{\text {th }}$ RAI, 443-60. Helsinki.

Oates, D. 1968: Studies in the Ancient History of Northern Iraq. London.

Oppenheim, A. L. 1965: On Royal Gardens in Mesopotamia, Journal of Near Eastern Studies 24, 328-33.

Orthmann, W. (ed.) 1975: Der Alte Orient. (Propyläen Kunstgeschichte 14). Berlin.

Postgate, J. N. and Reade, J. E. 1976-80: Kalhu, Reallexikon der Assyriologie 5, 303-23.

Reade, J. E. 1978: Studies in Assyrian Geography, Revue d'Assyriologie 72, 47-72 und 157-80.

Reade, J. E. 1998: Assyrian Illustrations of Nineveh, Iranica Antiqua 33, 81-94.

Reade, J. E. 1998-2001: Ninive, Reallexikon der Assyriologie 9, 388-433.

Stronach, D. 1990: The Garden as a Political Statement, Bulletin of the Asia Institute, New Series 4 (Festschrift Richard Nelson Frye: Aspects of Iranian Culture).

Weidner, E. 1959: Die Inschriften Tukulti-Ninurtas I. und seiner Nachfolger (Archiv für Orientforschung Beiheft 12). Graz.

Weiss, H. 1985: Tell Leilan, Biblical Archaeologist 48/1, 5-35.

Weiss, H. 1991: Leilan, American Journal of Archaeology 95, 703-7.

Weiss, H. et al. 1990: 1985: Excavations at Tell Leilan, Syria, American Journal of Archaeology 94, 529-81.

Winter, I. J. 1993: The Palace as Construct in the Ancient Near East, Ars Orientalis 23, 27-55.

Wiseman, D. J. 1983: Mesopotamian Gardens, Anatolian Studies 33, 135-44.

Wiseman, D. J. 1984: Palace and Temple Gardens in the Ancient Near East, in: H.I.H. Prince Takahito Mikasa (ed.), Monarchies and Socio-Religious Traditions on the Ancient Near East, 37-43. Wiesbaden. 